Article

\title{
Enhanced Photocatalytic Degradation of 2-Butanone Using Hybrid Nanostructures of Gallium Oxide and Reduced Graphene Oxide Under Ultraviolet-C Irradiation
}

\author{
Hyun Jeong Bae ${ }^{1}$, Tae Hee Yoo ${ }^{1}$, Seungdu Kim ${ }^{1}$, Wonhyeok Choi ${ }^{1}$, Yo Seung Song ${ }^{1}$, \\ Do-Kyun Kwon ${ }^{1}$, Byung Jin Cho ${ }^{2}$ and Wan Sik Hwang ${ }^{1, *}$ \\ 1 Department of Materials Engineering, Korea Aerospace University, Goyang 10540, Korea; \\ baehj83@gmail.com (H.J.B.); kauyootaehee@gmail.com (T.H.Y.); seungdukim@gmail.com (S.K.); \\ wonhyeok96@gmail.com (W.C.); yssong@kau.ac.kr (Y.S.S.); dkwon@kau.ac.kr (D.-K.K.) \\ 2 School of Electrical Engineering, KAIST, Daejeon 34141, Korea; bjcho@kaist.edu \\ * Correspondence: whwang@kau.ac.kr
}

Received: 20 April 2019; Accepted: 10 May 2019; Published: 15 May 2019

\begin{abstract}
Hybrid nanostructures made of gallium oxide $\left(\mathrm{Ga}_{2} \mathrm{O}_{3}\right)$ and reduced graphene oxide (rGO) are synthesized using a facile hydrothermal process method, where the $\mathrm{Ga}_{2} \mathrm{O}_{3}$ nanostructures are well dispersed on the rGO surface. The formed $\mathrm{Ga}_{2} \mathrm{O}_{3}-\mathrm{rGO}$ hybrids are characterized via Field emission scanning electron microscopy (FESEM), X-ray diffraction (XRD), Fourier transform infrared spectroscopy (FTIR), a diffuse reflectance Ultraviolet-visible-near infrared (UV-Vis-NIR) spectrophotometer, Brunauer-Emmett-Teller (BET), and photoluminescence (PL). Gas chromatography mass spectrometry (GC-MS) was used for analyzing volatile organic compounds (VOCs). The photocatalytic activity of the hybrid nanostructures is evaluated via the degradation of the 2-butanone, representing the VOCs under 254-nm radiation in the atmosphere. That activity is then compared to that of the $\mathrm{Ga}_{2} \mathrm{O}_{3}$ and commercial $\mathrm{TiO}_{2}-\mathrm{P} 25$. The $\mathrm{Ga}_{2} \mathrm{O}_{3}-\mathrm{rGO}$ hybrid shows enhanced photocatalytic degradation of 2-butanone compared to $\mathrm{Ga}_{2} \mathrm{O}_{3}$ and $\mathrm{TiO}_{2}-\mathrm{P} 25$, which is attributed to the enhanced specific surface area. The results indicate that the $\mathrm{Ga}_{2} \mathrm{O}_{3}-\mathrm{rGO}$ hybrid could be a promising method of enhancing photocatalytic activity and thereby effectively degrading VOCs, including the 2-butanone.
\end{abstract}

Keywords: gallium oxide $\left(\mathrm{Ga}_{2} \mathrm{O}_{3}\right)$; reduced graphene oxide (rGO); 2-butanone; volatile organic compounds (VOCs); photocatalytic oxidation (PCO); hydrothermal process; ultraviolet C (UVC) irradiation

\section{Introduction}

Volatile organic compounds (VOCs) with high vapor pressures at room temperature are everywhere because they are emitted from a wide range of consumer products, building materials and adhesives. Many VOCs are toxic and adversely affect the human body in both indoor and outdoor environments [1-3]. As human beings spend more time at home and in the work place, the control of VOCs in indoor environments is a critical concern [4]. While absorption and incineration methods have traditionally been used to remove VOCs, photocatalytic oxidation (PCO) using metal oxide semiconductors has emerged as an attractive alternative due to their low cost and non-toxicity [5]. The photo-induced generation of electron-hole pairs promotes reduction and oxidation upon the surface of the semiconducting transition metal oxides [6,7]. Among various semiconductors, $\mathrm{TiO}_{2}$ is preferred in terms of its photocatalytic activity under UV light absorption [8]. It has been widely applied to 
photocatalysts due to its nontoxicity, low cost and high reactivity. Nevertheless, its long-term instability greatly limits the practical applications, due to the deactivation of the photocatalytic sites resulting from the accumulation of a stable intermediate on the $\mathrm{TiO}_{2}$ surface from the oxidation of aromatics in a dry atmosphere $[9,10]$. Recently, interest has increased in $\mathrm{Ga}_{2} \mathrm{O}_{3}\left(\mathrm{E}_{\mathrm{g}}=4.8 \mathrm{eV}\right)$ as a wide band gap semiconductor with its high redox ability and long-term stability, compared to commercial $\mathrm{TiO}_{2}$ $\left(E_{g}=3.2 \mathrm{eV}\right)$, for the degradation of aromatic pollutants, such as the benzene series and toluene [11-15]. In addition to its strong redox ability, due to a higher conduction band $\left(\mathrm{E}_{\mathrm{cb}}=-1.55 \mathrm{eV}\right)$ and lower valence band $\left(\mathrm{E}_{\mathrm{vb}}=3.25 \mathrm{eV}\right)$ than $\mathrm{TiO}_{2}\left(\mathrm{E}_{\mathrm{cb}}=-0.5 \mathrm{eV}, \mathrm{E}_{\mathrm{vb}}=2.7 \mathrm{eV}\right)$ [16], $\mathrm{Ga}_{2} \mathrm{O}_{3}$ is composed of a valence band of $\mathrm{O} 2 \mathrm{p}$ orbitals and a dispersive conduction band of $\mathrm{s}$ and $\mathrm{p}$ orbitals from the p-block metal oxide atom, which promotes the mobility of photo-induced electrons in the $\mathrm{Ga}_{2} \mathrm{O}_{3}[13,17,18]$. This improves the separation efficiency of the photo-induced electrons and holes, resulting in an increase in photocatalytic activity. Advanced strategies to enhance photocatalytic activity have been reported via the formation of a heterogeneous structure with noble metals, semiconductors and/or graphene allotropes [19-22]. Among these materials, the addition of graphene oxide has been demonstrated to be an effective method due to its large specific surface area and excellent charge carrier mobility [5,21-26]. However, to the best of our knowledge, few studies thus far have looked at the photocatalytic degradation of gas-phase contaminants for the purification of enclosed atmospheres with the use of $\mathrm{Ga}_{2} \mathrm{O}_{3}$-reduced graphene oxide (rGO) hybrids under ultraviolet $\mathrm{C}$ (UVC) irradiation. The present study focuses on the photocatalytic degradation of 2-butanone, which is used in adhesives and cleaning agents, as an indoor VOC source $[27,28]$. Herein, we report on the synthesis of the $\mathrm{Ga}_{2} \mathrm{O}_{3}$-rGO hybrids formed using the hydrothermal method, and the photocatalytic degradation of 2-butanone is discussed as compared to $\mathrm{TiO}_{2}$ and $\mathrm{Ga}_{2} \mathrm{O}_{3}$.

\section{Results and Discussion}

Figure 1a shows the Field emission scanning electron microscope (FESEM) images of the rGO, $\mathrm{Ga}_{2} \mathrm{O}_{3}-\mathrm{rGO}$ hybrids and $\mathrm{Ga}_{2} \mathrm{O}_{3}$. The results showed that the rGO flakes were wrinkled, partially folded and stacked. This was attributed to the weakening of the hydrogen bonding network between the flakes and the generation of various structural defects during the hydrothermal process $[29,30]$. The images of the $\mathrm{Ga}_{2} \mathrm{O}_{3}-\mathrm{rGO}$ hybrids showed that the $\mathrm{Ga}_{2} \mathrm{O}_{3}$ nanorods were well dispersed and uniformly anchored on the rGO. The chemical bonds between the $\mathrm{Ga}_{2} \mathrm{O}_{3}$ and $\mathrm{rGO}$ were discussed via the Fourier transform infrared spectra (FTIR) analysis, thereby promoting the charge transfer of photo-excited carriers from the $\mathrm{Ga}_{2} \mathrm{O}_{3}$ to $\mathrm{rGO}$ and eventually enhancing the photocatalytic activity. The magnified image (inset of Figure 1a) of the $\mathrm{Ga}_{2} \mathrm{O}_{3}$ revealed that the $\mathrm{Ga}_{2} \mathrm{O}_{3}$ possessed a mesoporous surface that could contribute to the improvement of photocatalytic performance [31,32]. Figure $1 \mathrm{~b}$ shows the $\mathrm{X}$-ray diffraction (XRD) patterns of the pristine $\mathrm{GO}, \mathrm{rGO}, \mathrm{Ga}_{2} \mathrm{O}_{3}-\mathrm{rGO}$ hybrids and $\mathrm{Ga}_{2} \mathrm{O}_{3}$ nanorods. The pristine GO showed a very strong intensity at $2 \theta=10.55^{\circ}$, representing a typical inter-planar d-spacing $(0.84 \mathrm{~nm})$ of the GO stacks [33]. After the GO was reduced to rGO via the hydrothermal process, the peaks originating from the GO d-spacing diminished, but the broad peak at $2 \theta=24^{\circ}$ appeared, corresponding to the inter-planar d-spacing $(0.37 \mathrm{~nm})$ of the $\mathrm{rGO}$ [34]. The decreased d-spacing in the rGO compared to the GO was attributed to the removal of oxygen-containing functional groups, which also indicated the reestablishment of the $\mathrm{sp}^{2}$ carbon network in the rGO [35]. The results also revealed that the hydrothermal process was an effective method for the reduction of a GO without strong acidic conditions $[25,36]$. For Hybrid-2, the most noticeable peaks were indexed to the $\beta-\mathrm{Ga}_{2} \mathrm{O}_{3}$ with a broad rGO peak. As the ratio of $\mathrm{Ga}_{2} \mathrm{O}_{3}$ over rGO increased, the peaks representing $\mathrm{Ga}_{2} \mathrm{O}_{3}$ increased while the broad peak representing rGO diminished, as shown with Hybrid-1. These results showed that the $\mathrm{Ga}_{2} \mathrm{O}_{3}$ retained its crystal structure even after the hydrothermal process and dispersion on the rGO.

Figure 2 shows the FTIR spectra in the wavenumber range from 4000 to $650 \mathrm{~cm}^{-1}$, along with a schematic drawing representing the responsible chemical bonds of the pristine $\mathrm{GO}, \mathrm{rGO}, \mathrm{Ga}_{2} \mathrm{O}_{3}-\mathrm{rGO}$ hybrids and $\mathrm{Ga}_{2} \mathrm{O}_{3}$. The spectrum of the pristine $\mathrm{GO}$ showed typical transmittance peaks. The bands in the range of 1700 to $1000 \mathrm{~cm}^{-1}$ were associated with oxygen functional groups such as the carboxyl 
groups, hydroxyl groups and epoxy groups on both sides of the GO surface [24,36,37]. These bands of oxygen functional groups in the GO significantly decreased after the formation of $\mathrm{rGO}$ via the hydrothermal process $[34,38]$. This revealed that most oxygen functional groups had been removed from the GO surface while the GO was reduced [29]. These eliminated peaks associated with the oxygen functional group were recovered in the spectra of the $\mathrm{Ga}_{2} \mathrm{O}_{3}-\mathrm{rGO}$ hybrids. The presence of these oxygen functional groups indicated the formation of the chemical bonds between the $\mathrm{Ga}_{2} \mathrm{O}_{3}$ nanorods and the $\mathrm{rGO}$, which allowed the carrier transfer from the $\mathrm{Ga}_{2} \mathrm{O}_{3}$ to $\mathrm{rGO}$, and thereby enhanced the photocatalytic activity.

(a)

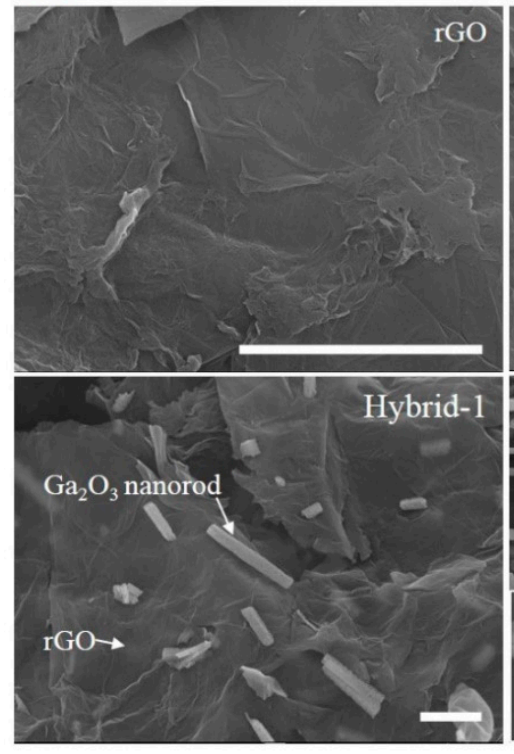

(b)

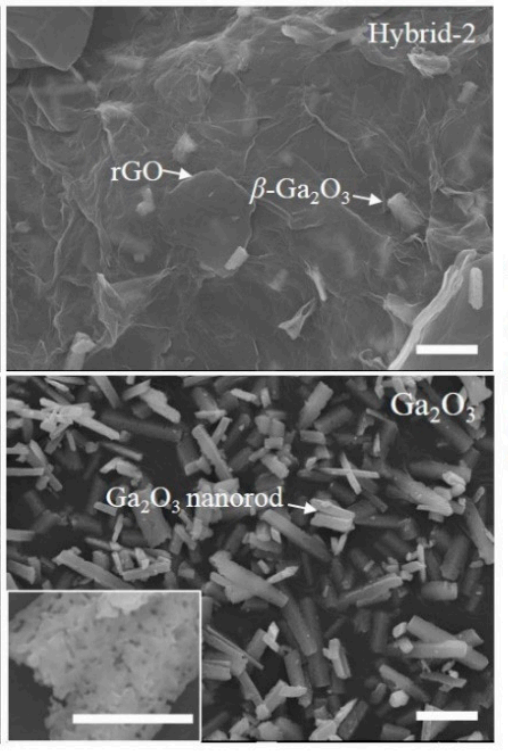

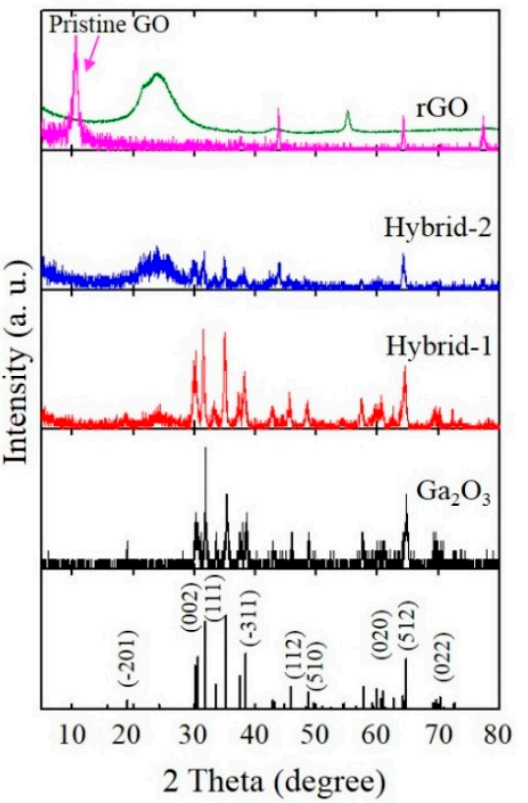

Figure 1. (a) FESEM images of rGO, Hybrid-2, Hybrid-1 and $\mathrm{Ga}_{2} \mathrm{O}_{3}$ (the scale bar is $3 \mu \mathrm{m}$ ); the scale bar of the inset is $1 \mu \mathrm{m}$ ), and (b) XRD patterns of the pristine GO, rGO, Hybrid-2, Hybrid-1 and $\mathrm{Ga}_{2} \mathrm{O}_{3}$ with the reference from Joint Committee on Powder Diffraction Standards (JCPDS) card no. 760573 (monoclinic $\mathrm{Ga}_{2} \mathrm{O}_{3}$ phase).

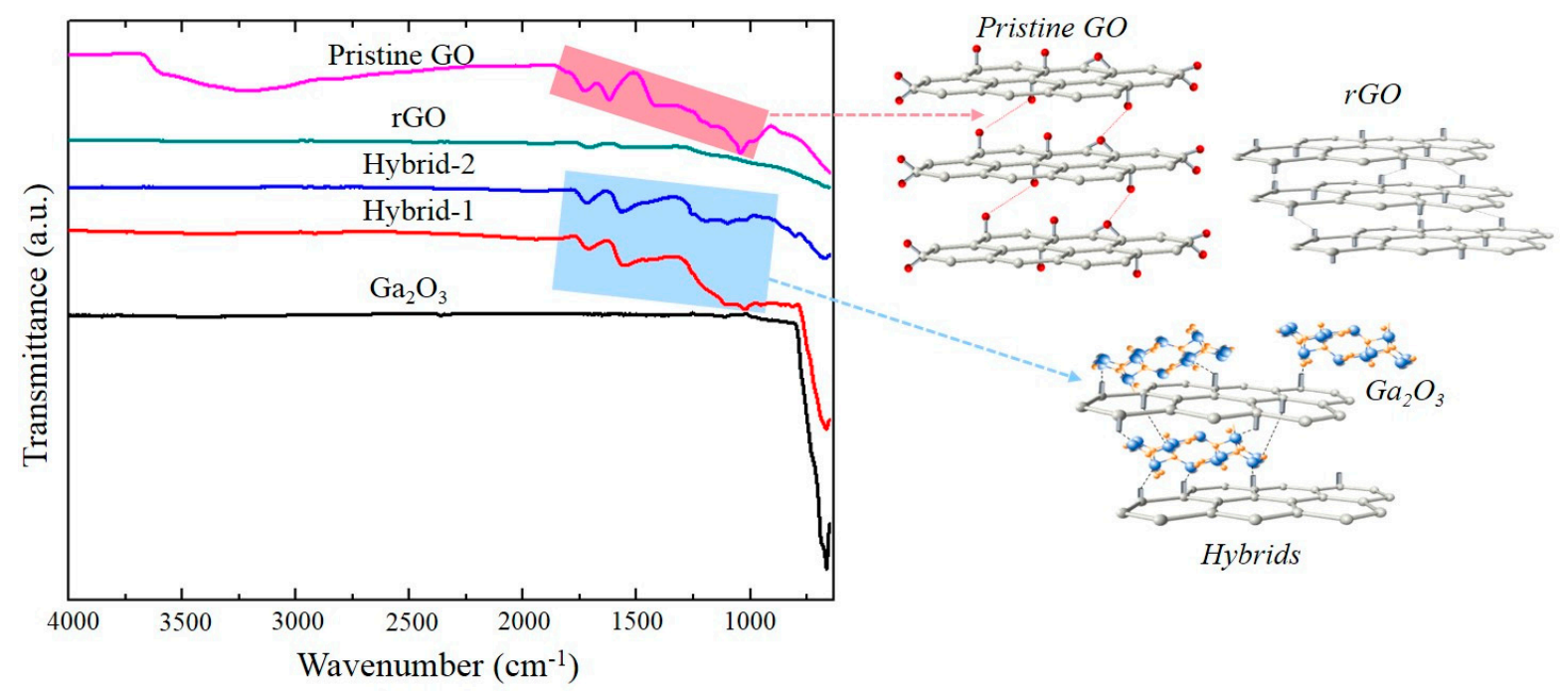

Figure 2. FTIR spectra of pristine $\mathrm{GO}, \mathrm{rGO}$, Hybrid-2, Hybrid-1 and $\mathrm{Ga}_{2} \mathrm{O}_{3}$, along with schematic chemical structure of $\mathrm{GO}, \mathrm{rGO}$ and $\mathrm{Ga}_{2} \mathrm{O}_{3}$-rGO hybrids. 
The Ultraviolet-visible-near infrared (UV-Vis-NIR) absorption of the $\mathrm{Ga}_{2} \mathrm{O}_{3}$ and hybrids were characterized in the wavelength range of 240 to $1000 \mathrm{~nm}$, and the results are shown in Figure 3a. These results showed that the $\mathrm{Ga}_{2} \mathrm{O}_{3}$ was transparent in the visible light and ultraviolet $\mathrm{C}$. As the ratio of the rGO over $\mathrm{Ga}_{2} \mathrm{O}_{3}$ increased, the overall absorption from the visible and near infrared (400-1000 nm) into the UV wavelength regions $(260 \mathrm{~nm} \sim)$ increased. In detail, a red shift in the absorption edge was observed in Hybrid-1 compared with $\mathrm{Ga}_{2} \mathrm{O}_{3}$, indicating a narrowing of the $\mathrm{Ga}_{2} \mathrm{O}_{3}$ band gap due to the coupling in the $\mathrm{Ga}_{2} \mathrm{O}_{3}-\mathrm{rGO}$ hybrids. The inset in Figure 3a shows the Tauc plot for the $\mathrm{Ga}_{2} \mathrm{O}_{3}$ and $\mathrm{Ga}_{2} \mathrm{O}_{3}-\mathrm{rGO}$ hybrids, where $(\mathrm{ah} v)^{2}$ was plotted against the photo energy (hv), and the band gap energies were calculated from the extrapolated lines as shown. The optical energy band gap of the $\mathrm{Ga}_{2} \mathrm{O}_{3}$ and Hybrid-1 was calculated as 4.63 and $4.25 \mathrm{eV}$, respectively. However, it was difficult to calculate the exact optical energy band gap for Hybrid-2 because the large amount of rGO induced a very significant background absorption in the range of 400 to $800 \mathrm{~nm}$. Also, while the absorption of Hybrid-1 around $254 \mathrm{~nm}$ was comparable to that of $\mathrm{Ga}_{2} \mathrm{O}_{3}$, the absorption of Hybrid-2 (a greater rGO ratio) was greatly reduced. This indicated that the photogenerated electrons from the $\mathrm{Ga}_{2} \mathrm{O}_{3}$ in Hybrid-1 were able to move along the $\mathrm{rGO}$ and then interact with the absorbed $\mathrm{O}_{2}$ to produce $\mathrm{OH}$, which facilitated the strong oxidative ability to degrade the organic pollutants. In this process, the rGO acted as an electron collector and transporter to effectively interfere with the electron-hole recombination and extend the lifetime of the photogenerated charge carriers formed by $\mathrm{Ga}_{2} \mathrm{O}_{3}$, leading to the higher photocatalytic efficiency in Hybrid-1. However, with the excessive addition of rGO (Hybrid-2), the rGO nanosheets blocked the UVC light from reaching the surface of the $\mathrm{Ga}_{2} \mathrm{O}_{3}$, resulting in the lower generation rate of the charge carriers. Figure $3 b$ shows the PL emission spectra of the $\mathrm{Ga}_{2} \mathrm{O}_{3}$, Hybrid- 1 and -2 when excited at $260 \mathrm{~nm}$. A broad emission band ranging from 300 to $500 \mathrm{~nm}$ was observed in the $\mathrm{Ga}_{2} \mathrm{O}_{3}$ spectrum, while considerable PL quenching was observed in the hybrids with higher ratios of $\mathrm{rGO}$ over $\mathrm{Ga}_{2} \mathrm{O}_{3}$. The decreased intensity of the PL emission might have been due to the reduction in the recombination process of electrons and holes because of the charge carrier transfer from the excited $\mathrm{Ga}_{2} \mathrm{O}_{3}$ to the $\mathrm{rGO}[23,39,40]$. To further discuss the charge carrier transfer from the excited $\mathrm{Ga}_{2} \mathrm{O}_{3}$ to the $\mathrm{rGO}$, the PL decay characteristics of the $\mathrm{Ga}_{2} \mathrm{O}_{3}$ and hybrids were investigated, as shown in the inset of Figure $3 \mathrm{~b}$. The results were fitted to multi-exponential curves to derive the PL decay parameters that were obtained using Equations (1) and (2) [41]. The lifetime, pre-exponential factors and average lifetime of the $\mathrm{Ga}_{2} \mathrm{O}_{3}$ and hybrids are summarized in Table 1.

$$
\begin{gathered}
f(t)=A_{1} e^{\frac{t}{\tau_{1}}}+A_{2} e^{\frac{t}{\tau_{2}}}+A_{3} e^{\frac{t}{\tau_{3}}}+A_{4} e^{\frac{t}{\tau_{4}}} \\
\langle\tau\rangle=\sum_{i=1}^{n} \frac{A_{i} \tau_{i}^{2}}{A_{i} \tau_{i}}
\end{gathered}
$$

where $A_{i}$ denotes the pre-exponential factor, $\tau_{i}$ is the lifetime decay constant, and $\langle\tau\rangle$ is the average lifetime.

For the $\mathrm{Ga}_{2} \mathrm{O}_{3}$, the fast and slow component of the PL decay had a lifetime of $2.5 \mathrm{~ns}$ and $2876 \mathrm{~ns}$, respectively. As the ratio of the $\mathrm{rGO}$ over $\mathrm{Ga}_{2} \mathrm{O}_{3}$ increased, the fast lifetime and average lifetime decreased, but the slow lifetime increased. The analysis revealed that the charge carrier transfer between the excited $\mathrm{Ga}_{2} \mathrm{O}_{3}$ and $\mathrm{rGO}$ was dominated by the fast component. Furthermore, from the fast decay component, the electron-transfer rate could be estimated using Equation (3).

$$
k_{e t}=\frac{1}{\tau}\left(G a_{2} \mathrm{O}_{3}-r G O\right)-\frac{1}{\tau}\left(G a_{2} \mathrm{O}_{3}\right)
$$

The electron-transfer rate of Hybrid-1 was $0.017 \times 10^{9} \mathrm{~s}^{-1}$, while that of Hybride-2 was $0.225 \times 10^{9} \mathrm{~s}^{-1}$. This showed that the electron-transfer rate of Hybrid-2 was 13.5 times higher than that of Hybrid-1, while the number of electron-hole pairs was lower in Hybrid-2. Based on this analysis, it was concluded that the chemical bonds between the $\mathrm{Ga}_{2} \mathrm{O}_{3}$ and rGO were very effective in transferring the photo-excited electrons before the recombination process. 
(a)

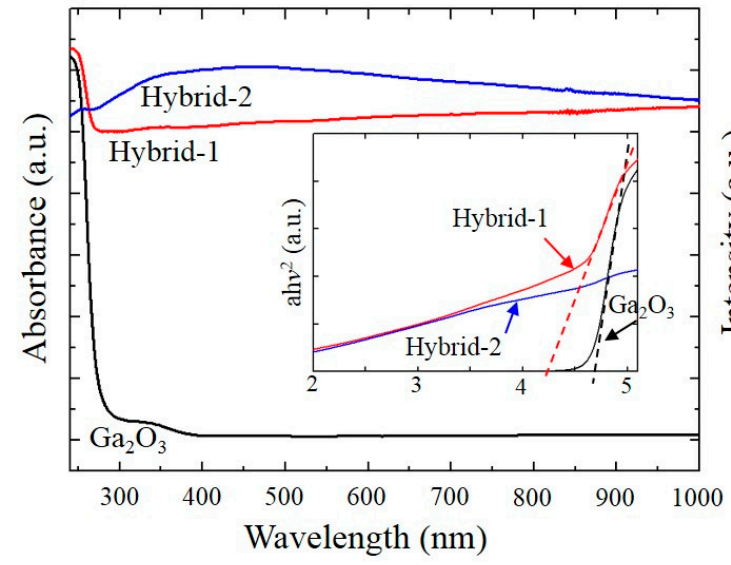

(b)

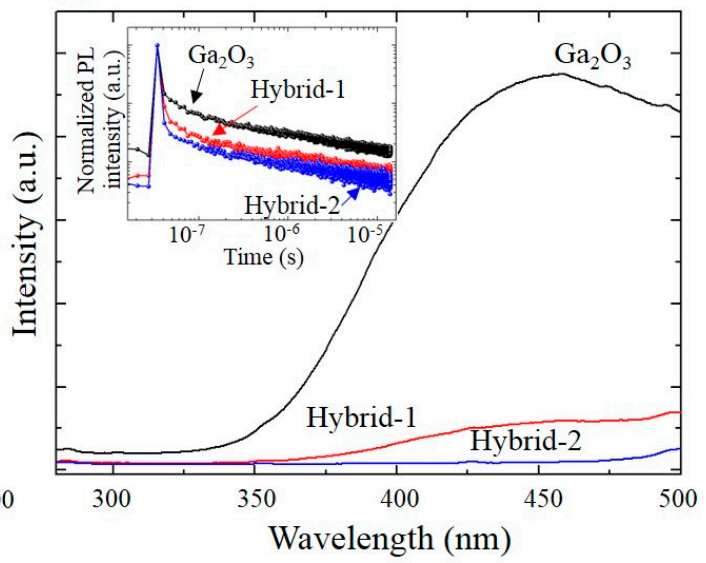

Figure 3. (a) UV-Vis-NIR spectroscopy and (b) PL spectroscopy of $\mathrm{Ga}_{2} \mathrm{O}_{3}$ and $\mathrm{Ga}_{2} \mathrm{O}_{3}$-rGO hybrids at room temperature. The inset in Figure 3a shows a Tauc plot, which is one method of extracting an optical energy bandgap in semiconductors. The inset in Figure $3 \mathrm{~b}$ shows the normalized PL decay of the $\mathrm{Ga}_{2} \mathrm{O}_{3}$ and $\mathrm{Ga}_{2} \mathrm{O}_{3}-\mathrm{rGO}$ hybrids, which was measured at the emission wavelengths of $455 \mathrm{~nm}$ and $459 \mathrm{~nm}$, respectively.

Table 1. Summary of the fitting parameters for the PL decay components of the $\mathrm{Ga}_{2} \mathrm{O}_{3}$ and hybrids.

\begin{tabular}{cccccccccc}
\hline & $\boldsymbol{A}_{\mathbf{1}}$ & $\boldsymbol{\tau}_{\mathbf{1}}$ (ns) & $\boldsymbol{A}_{\mathbf{2}}$ & $\boldsymbol{\tau}_{\mathbf{2}}$ (ns) & $\boldsymbol{A}_{\mathbf{3}}$ & $\boldsymbol{\tau}_{\mathbf{3}}$ (ns) & $\boldsymbol{A}_{\mathbf{4}}$ & $\boldsymbol{\tau}_{\mathbf{4}}$ (ns) & $\langle\boldsymbol{\tau}\rangle(\mathbf{n s})$ \\
\hline $\mathrm{Ga}_{2} \mathrm{O}_{3}$ & 8973 & 2.5 & 0 & & 603 & 110 & 201 & 2876 & 68.3 \\
Hybrid-1 & 9538 & 2.4 & 0 & & 236 & 126 & 81 & 3081 & 30.7 \\
Hybrid-2 & 9597 & 1.6 & 186 & 43.6 & 59 & 419 & 49 & 4171 & 25.7 \\
\hline
\end{tabular}

The identification of the adhesive component was measured with a GC-MS analysis, which was identified by comparing retention times and mass spectra with library spectra. Figure 4a shows that air, water and 2-butanone were detected before the photodegradation. After UVC irradiation of the 2-butanone for $30 \mathrm{~min}$ using a $\mathrm{Ga}_{2} \mathrm{O}_{3}$-rGO hybrid (Figure $4 \mathrm{~b}$ ), it was found that air and water were the main by-products. Figure $4 \mathrm{c}$ shows the degradation of 2-butanone as a function of exposure time under the $254 \mathrm{~nm}$ UVC irradiation time, at intervals of $30 \mathrm{~min}$ when different catalysts were used. The $\mathrm{TiO}_{2}-\mathrm{P} 25$, which is known to be a good photocatalyst, was also compared with its counterparts under the identical reaction conditions. With conventional $\mathrm{TiO}_{2}-25$, the 2-butanone degraded to $62 \%$ within $1 \mathrm{~h}$. On the other hand, the 2-butanone degraded to $93 \%$ within $1 \mathrm{~h}$ when $\mathrm{Ga}_{2} \mathrm{O}_{3}$ was used as a catalyst. The hybrids showed a much-enhanced photodegradation efficiency compared to the $\mathrm{Ga}_{2} \mathrm{O}_{3}$ and $\mathrm{TiO}_{2}$. The 2-butanone degraded to $99.9 \%$ and $98.2 \%$ under the identical conditions when Hybrid-1 and Hybrid-2 were used, respectively. The additional rGO in the $\mathrm{Ga}_{2} \mathrm{O}_{3}$ played a role as a transfer pathway of the photo-generated carriers. In addition, the rGO provided a much higher specific surface area, improving the photocatalytic performance of the $\mathrm{Ga}_{2} \mathrm{O}_{3}$. It was found that Hybrid-1 had a higher specific surface area $\left(\mathrm{S}_{\mathrm{BET}}=149 \mathrm{~m}^{2} \cdot \mathrm{g}^{-1}\right)$ than the pure $\mathrm{Ga}_{2} \mathrm{O}_{3}\left(\mathrm{~S}_{\mathrm{BET}}=3.4 \mathrm{~m}^{2} \cdot \mathrm{g}^{-1}\right)$ and Hybrid-2 $\left(\mathrm{S}_{\mathrm{BET}}=36 \mathrm{~m}^{2} \cdot \mathrm{g}^{-1}\right)$, using the Brunauer-Emmett-Teller (BET) surface area measurement $[42,43]$. While the additional rGO in the $\mathrm{Ga}_{2} \mathrm{O}_{3}$ improved the photocatalytic performance via the reasons above mentioned, it adversely degraded the photocatalytic performance due to the lower UVC absorption blocked by excessive rGO [20,34], which could be observed in Figure 3a. This explained the experimental results; the degradation performance of different catalysts was in the order of Hybrid-1 (1 wt. \% of rGO) > Hybrid-2 ( 5 wt. $\%$ of $\mathrm{rGO}$ ) $>\mathrm{Ga}_{2} \mathrm{O}_{3}>\mathrm{TiO}_{2}$-P25. In addition to the photocatalytic activity, the stability and repeatability of the 2-butanone degradation was investigated using Hybrid-1, with the results shown in Figure $4 \mathrm{~d}$. The results showed that Hybrid-1 retained its photocatalytic activity even after prolonged operation.

Figure 5 shows the optical transmittance of Hybrid- 1 before and after 2-butanone degradation. The transmittance decreased after 2-butanone degradation particularly around $1710 \mathrm{~cm}^{-1}$ and $1560 \mathrm{~cm}^{-1}$, 
representing $\mathrm{C}=\mathrm{O}$ bonding [12] and $\mathrm{C}=\mathrm{C}$ bonding [44], respectively. This indicated that the decomposed residue of the 2-butanone remained on the Hybrid-1 surface. These residual byproducts on the surface need to be investigated further.

(a)

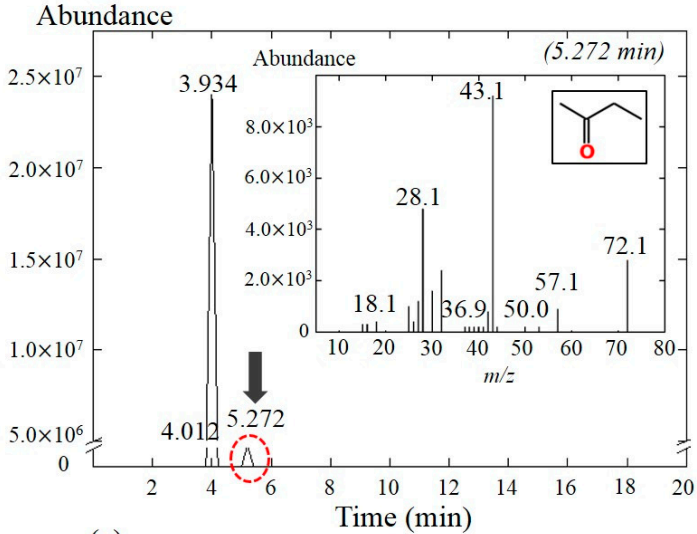

(c)

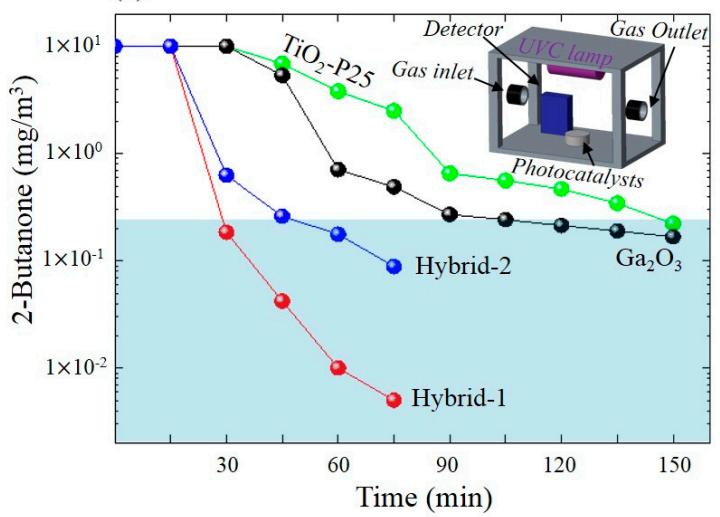

(b)

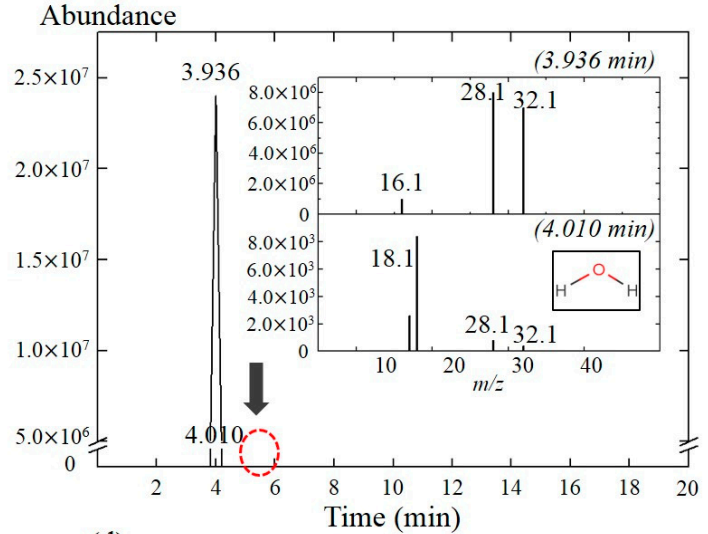

(d)

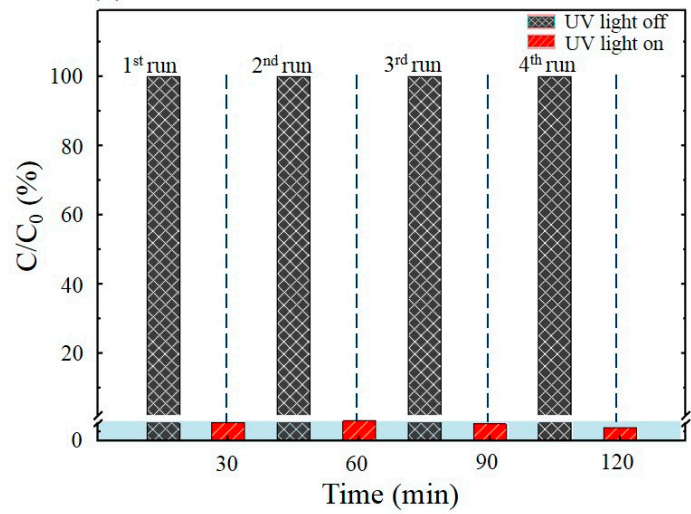

Figure 4. Gas chromatography graph (a) before and (b) after photodegradation under $254 \mathrm{~nm}$ UVC irradiation for $30 \mathrm{~min}$. (The inset in (a) is the mass spectrum of 2-butanone, and the inset in (b) is the mass spectra of $\mathrm{H}_{2} \mathrm{O}$ and air), (c) photodegradation of 2-butanone under $254 \mathrm{~nm}$ UVC irradiation with different catalysts such as $\mathrm{TiO}_{2}-\mathrm{P} 25, \mathrm{Ga}_{2} \mathrm{O}_{3}$ and $\mathrm{Ga}_{2} \mathrm{O}_{3}-\mathrm{rGO}$ hybrids. TVOC refers to the total volatile organic compounds and a group of a wide range of organic chemical compounds. The guideline below $0.3 \mathrm{mg} / \mathrm{m}^{3}$ provides practical guidance to manage health and safety risks, which are regulated under Health and Safety, and subject to change (inset: Schematic drawing of the photocatalytic reactor), and (d) repeatability test of photocatalytic degradation of Hybrid-1 under $254 \mathrm{~nm}$ UVC irradiation at intervals of $15 \mathrm{~min}$.

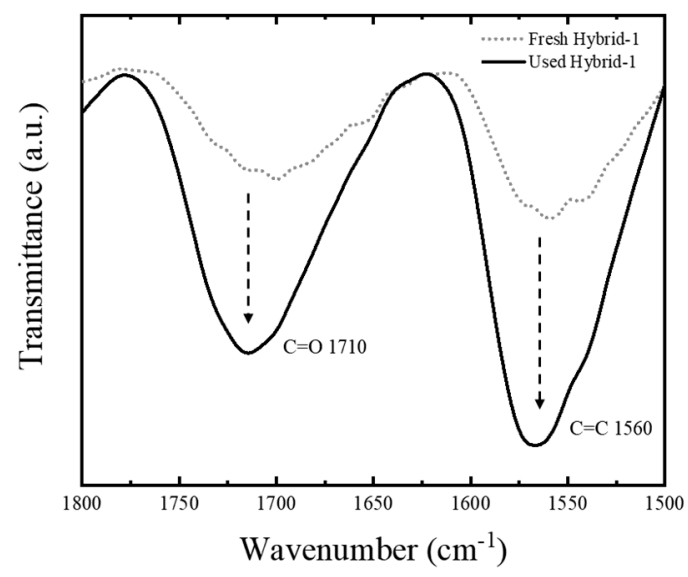

Figure 5. Optical transmittance of fresh Hybrid-1 and used Hybrid-1 as a function of wavelength. 


\section{Materials and Methods}

\subsection{Synthesis of Hybrids}

The GO was prepared using a modified Hummers' method [45], and the $\mathrm{Ga}_{2} \mathrm{O}_{3}$ powder (particle diameter 2.5-6 $\mu \mathrm{m}, 99.999 \%$ ) was purchased from Taewon Scientific Co., Ltd. (Republic of Korea). $\mathrm{Ga}_{2} \mathrm{O}_{3}-\mathrm{rGO}$ hybrids were synthesized via a conventional hydrothermal method. First, a GO solution in which the GO (lateral size $>3 \mu \mathrm{m}, 99 \%$ ) was dispersed in distilled water (DI water, $50 \mathrm{~mL}$ ) was ultrasonicated for $3 \mathrm{~h}$ to obtain uniform dispersions of exfoliated GO. Next, $\mathrm{Ga}_{2} \mathrm{O}_{3}$ powders were added into the prepared GO solutions. After being vigorously stirred for $2 \mathrm{~h}$, the mixture of $\mathrm{Ga}_{2} \mathrm{O}_{3}$ and GO solutions was transferred to a Teflon-lined autoclave for the hydrothermal process. The mixed solution was heated in an oven at $150{ }^{\circ} \mathrm{C}$ for $6 \mathrm{~h}\left(6^{\circ} \mathrm{C} \mathrm{min}{ }^{-1}\right)$ and cooled at room temperature. The unreacted solvent and the resulting precipitate were separated by centrifugal force at $4000 \mathrm{rpm}$ for $30 \mathrm{~min}$. The collected precipitate was washed and rinsed with DI water and ethanol several times and then dried at $60{ }^{\circ} \mathrm{C}$ for $12 \mathrm{~h}\left(6^{\circ} \mathrm{C} \mathrm{min}{ }^{-1}\right)$. Finally, two $\mathrm{Ga}_{2} \mathrm{O}_{3}-\mathrm{rGO}$ hybrids with $1 \mathrm{wt} . \%$ and 5 wt. \% of rGO were formed, which were called Hybrid-1 and Hybrid-2, respectively. It was noted that the GO was successfully converted into rGO without strong acidic conditions via the hydrothermal process.

\subsection{Materials Characterization}

The microstructures of the synthesized $\mathrm{Ga}_{2} \mathrm{O}_{3}-\mathrm{rGO}$ hybrids were observed using a field emission scanning electron microscope (FESEM, JEOL JSM-7100F, Japan) at $15 \mathrm{kV}$ acceleration voltage; the samples were distributed on the sticky-carbon tape followed by a Pt coating. The crystallographic structures of the synthesized hybrids were determined using a powder X-ray diffraction system (XRD, Rigaku Ultima IV XRD, Japan) over the $2 \theta$ range of $5-80^{\circ}$ with $\mathrm{Cu} \mathrm{K} \alpha$ radiation $(\lambda=0.15405 \mathrm{~nm})$. Middle-infrared (4000-650 $\mathrm{cm}^{-1}$ ) transmission spectra were collected with a Fourier-transform infrared spectra (FTIR, Agilent Cary 670, U.S.A.) spectrometer with an ATR accessory (ZnSe and Ze crystal). UV-Vis-NIR spectroscopy (DRS, Shimadzu SolidSpec-3700, Japan) was measured in the range from 240 to $1000 \mathrm{~nm}$ using $\mathrm{BaSO}_{4}$ as a reference. Photoluminescence (PL) spectra were recorded under 260 nm UV laser excitation (PL, HORIBA LabRAM HR-800, Japan). Furthermore, Time-resolved PL measurements were performed on a HORIBA Fluorolog-3 via a time-correlated single photon counting (TCSPC) spectrometer equipped with a Pulsed Nano LED 260-nm excitation source. The specific surface area of the product was measured using a nitrogen adsorption-desorption isotherm on a BELSORP-max instrument and calculated via the Brunauer-Emmett-Teller (BET) method. Prior to measurement, the samples were degassed at $473 \mathrm{~K}$ for $4 \mathrm{~h}$.

\subsection{Photocatalytic Activity}

The photocatalytic performance of the $\mathrm{Ga}_{2} \mathrm{O}_{3}-\mathrm{rGO}$ hybrids with different rGO wt. \% were evaluated via the photodegradation of 2-butanone using a commercial VOC air detector (KHALDER: KD-001) with TVOC values ranging between 0.00 to $9.99 \mathrm{mg} / \mathrm{m}^{3}$. For every experiment, $200 \mathrm{mg}$ of the photocatalyst powder and $18.2 \mathrm{mg}$ of a commercial adhesive (as a 2-butanone source) were used with a UVC source $\left(\lambda=254 \mathrm{~nm}, 4 \mathrm{~W}\right.$, irradiance of $340 \mu \mathrm{W} \cdot \mathrm{cm}^{-2}$ with a distance of $15 \mathrm{~cm}$, Model: LF-104.S). No noticeable degradation of the 2-butanone was observed in the absence of a photocatalyst under the UVC irradiation. In the presence of a photocatalyst under UVC exposure, the photodegradation efficiency was calculated using Equation (4):

$$
\text { Degradation efficiency }(\%)=\left(C_{0}-C\right) / C_{0} \times 100
$$

where $C_{0}$ is the initial concentration and $C$ is the final concentration of the 2-butanone. Changes in the 2-butanone concentration were measured at intervals of $30 \mathrm{~min}$. For comparison, photodegradation efficiency of $\mathrm{Ga}_{2} \mathrm{O}_{3}$ and $\mathrm{TiO}_{2}-\mathrm{P} 25$ was also carried out. To further explore the long-term stability of the $\mathrm{Ga}_{2} \mathrm{O}_{3}-\mathrm{rGO}$ hybrids, repeated recycling experiments were carried out using Hybrid-1 under 
identical conditions. The gaseous products generated before and after the photocatalytic degradation were collected and analyzed with a gas chromatograph (GC, Agilent 5975C, U.S.A.) equipped with a HP-5 MS column (with dimensions of $60 \mathrm{~m} \times 0.25 \mu \mathrm{m} \times 0.25 \mathrm{~mm}$ ). A product sample was injected into the GC column with a split ratio 20:1. Helium was used as the carrier gas at a flow rate of $1.0 \mathrm{~mL} \cdot \mathrm{min}^{-1}$. The column temperature program was as follows: $50{ }^{\circ} \mathrm{C}$ for $10 \mathrm{~min}$, increasing at a rate of $10^{\circ} \mathrm{C} \mathrm{min}^{-1}$ to $300{ }^{\circ} \mathrm{C}$. The product identification was confirmed with a gas chromatograph-mass spectrometer. Major reaction products were identified by comparing retention times and mass spectra with reference compounds.

\section{Conclusions}

$\mathrm{Ga}_{2} \mathrm{O}_{3}$-rGO hybrids were synthesized using a facile hydrothermal process method without using any additives or surfactants. The $\mathrm{Ga}_{2} \mathrm{O}_{3}$ nanorods were well dispersed on the surface of the rGO nanosheet through strong coupling between the $\mathrm{Ga}_{2} \mathrm{O}_{3}$ and rGO. Compared with the pure $\mathrm{Ga}_{2} \mathrm{O}_{3}$ and conventional $\mathrm{TiO}_{2}-\mathrm{P} 25$, the photocatalytic activity of the hybrids was significantly enhanced. The enhanced photocatalytic activity of the hybrids was attributed to the effective carrier transfer from the $\mathrm{Ga}_{2} \mathrm{O}_{3}$ to $\mathrm{rGO}$ and enhanced specified surface area. The best photocatalytic activity was observed with Hybrid-1 (1 wt. \% rGO) instead of Hybrid-2 (5 wt. \% rGO), indicating that the presence of rGO with $\mathrm{Ga}_{2} \mathrm{O}_{3}$ can also degrade the photocatalytic performance via the lower absorption of UVC light blocked by the excessive $\mathrm{rGO}$. The $\mathrm{Ga}_{2} \mathrm{O}_{3}$-rGO hybrid offers a promising method of enhancing photocatalytic activity and thereby effectively degrading 2-butanone.

Author Contributions: Conceptualization, B.J.C., W.S.H.; formal analysis, H.J.B., T.H.Y., S.K., W.C.; methodology and resources, Y.S.S., D.-K.K., B.J.C., W.S.H.; writing, review and editing, H.J.B., T.H.Y., S.K., W.C., Y.S.S., D.-K.K., B.J.C., W.S.H.

Funding: This work was funded by the National Research Foundation of Korea (NRF) through the Basic Science Research Program (2017R1A2B4012278), and by the Center for Advanced Soft-Electronics that is funded by the Ministry of Science, ICT and Future Planning, through the Global Frontier Project (CASE-2011-0031638).

Acknowledgments: Gas chromatography mass spectrometry (GC-MS) analysis was conducted at Korea Basic Science Institute (Busan Center).

Conflicts of Interest: The authors declare no conflict of interest.

\section{References}

1. Dolai, S.; Bhunia, S.K.; Beglaryan, S.S.; Kolusheva, S.; Zeiri, L.; Jelinek, R. Colorimetric Polydiacetylene-Aerogel Detector for Volatile Organic Compounds (VOCs). ACS Appl. Mater. Interfaces 2017, 9, 2891-2898. [CrossRef] [PubMed]

2. Konvalina, G.; Haick, H. Sensors for Breath Testing: From Nanomaterials to Comprehensive Disease Detection. Acc. Chem. Res. 2014, 47, 66-76. [CrossRef] [PubMed]

3. Suh, J.M.; Sohn, W.B.; Shim, Y.S.; Choi, J.S.; Song, Y.G.; Kim, T.M.; Jeon, J.M.; Kwon, K.C.; Choi, K.S.; Kang, C.Y.; et al. p-p Heterojunction of Nickel Oxide-Decorated Cobalt Oxide Nanorods for Enhanced Sensitivity and Selectivity toward Volatile Organic Compounds. ACS Appl. Mater. Interfaces 2018, 10, 1050-1058. [CrossRef] [PubMed]

4. McCurdy, T.; Glen, G.; Smith, L.; Lakkadi, Y. The National Exposure Research Laboratory's Consolidated Human Activity Database. J. Expo. Anal. Environ. Epidemiol. 2000, 10, 566-578. [CrossRef]

5. Kim, S.D.; Han, K.I.; Lee, I.G.; Park, W.K.; Yoon, Y.J.; Yoo, C.S.; Yang, W.S.; Hwang, W.S. A Gallium Oxide-Graphene Oxide Hybrid Composite for Enhanced Photocatalytic Reaction. Nanomaterials 2016, 6, 127. [CrossRef]

6. Devahasdin, S.; Fan, C., Jr.; Li, K.; Chen, D.H. $\mathrm{TiO}_{2}$ photocatalytic oxidation of nitric oxide: Transient behavior and reaction kinetics. J. Photochem. Photobiol. A 2003, 156, 161170. [CrossRef]

7. Kamal, M.S.; Razzak, S.A.; Hossain, M.M. Catalytic oxidation of volatile organic compounds (VOCs)-A review. Atmos. Environ. 2016, 140, 117-134. [CrossRef]

8. Tatsuma, T.; Saitoh, S.; Ngaotrakanwiwat, P.; Ohko, Y.; Fujishima, A. Energy Storage of $\mathrm{TiO}_{2}-\mathrm{WO}_{3}$ Photocatalysis Systems in the Gas Phase. Langmuir 2002, 18, 7777-7779. [CrossRef] 
9. Martra, G.; Coluccia, S.; Marchese, L.; Augugliaro, V.; Loddo, V.; Palmisano, L.; Schiavello, M. The Role of $\mathrm{H}_{2} \mathrm{O}$ in the Photocatalytic Photocatalytic Oxidation of Toluene in Vapour Phase on Anatase $\mathrm{TiO}_{2}$ Catalyst: A FTIR Study. Catal. Today 1999, 53, 695-702. [CrossRef]

10. Mendez-Roman, R.; Cardona-Martinez, N. Relationship between the Formation of Surface Species and Catalyst Deactivation during the Gas-Phase Photocatalytic Oxidation of Toluene. Catal. Today 1998, 40, 353-365. [CrossRef]

11. Girija, K.; Thirumalairajan, S.; Patra, A.K.; Mangalaraj, D.; Ponpandian, N.; Viswanathan, C. Enhanced photocatalytic performance of novel self-assembled floral $\beta-\mathrm{Ga}_{2} \mathrm{O}_{3}$ nanorods. Curr. Appl. Phys. 2013, 13, 652-658. [CrossRef]

12. Hou, Y.; Wang, X.; Wu, L.; Ding, Z.; Fu, X. Efficient Decomposition of Benzene over a $\beta-\mathrm{Ga}_{2} \mathrm{O}_{3}$ Photocatalyst under Ambient Conditions. Environ. Sci. Technol. 2006, 40, 5799-5803. [CrossRef] [PubMed]

13. Hou, Y.; Wu, L.; Wang, X.; Ding, Z.; Li, Z.; Fu, X. Photocatalytic performance of $\alpha-$-, $\beta$-, and $\gamma-\mathrm{Ga}_{2} \mathrm{O}_{3}$ for the destruction of volatile aromatic pollutants in air. J. Catal. 2007, 250, 12-18. [CrossRef]

14. Hou, Y.; Zhang, J.S.; Ding, Z.X.; Wu, L. Synthesis, characterization and photocatalytic activity of $\beta-\mathrm{Ga}_{2} \mathrm{O}_{3}$ nanostructures. Powder Technol. 2010, 203, 440-446. [CrossRef]

15. Sun, M.; Li, D.; Zhang, W.; Fu, X.; Shao, Y.; Li, W.; Xiao, G.; He, Y. Rapid microwave hydrothermal synthesis of $\mathrm{GaOOH}$ nanorods with photocatalytic activity toward aromatic compounds. Nanotechnology 2010, 21, 355601. [CrossRef] [PubMed]

16. Liu, Q.; Yu, Z.; Li, M.; Hou, Y.; Sun, L.; Wang, L.; Peng, Z.; Chen, D.; Liu, Y. Fabrication of Ag/ $\mathrm{AgBr} / \mathrm{Ga}_{2} \mathrm{O}_{3}$ heterojunction composite with efficient photocatalytic activity. Mol. Catal. 2017, 432, 57-63. [CrossRef]

17. Ikarashi, K.; Sato, J.; Kobayashi, H.; Saito, N.; Nishiyama, H.; Inoue, Y. Photocatalysis for Water Decomposition by $\mathrm{RuO}_{2}$-Dispersed $\mathrm{ZnGa}_{2} \mathrm{O}_{4}$ with $\mathrm{d}_{10}$ Configuration. J. Phys. Chem. B 2002, 106, 9048-9053. [CrossRef]

18. Sato, J.; Kobayashi, H.; Ikarashi, K.; Saito, N.; Nishiyama, H.; Inoue, Y. Photocatalytic Activity for Water Decomposition of $\mathrm{RuO}_{2}$-Dispersed $\mathrm{Zn}_{2} \mathrm{GeO}_{4}$ with $\mathrm{d}_{10}$ Configuration. J. Phys. Chem. B 2004, 108, 4369-4375. [CrossRef]

19. Ge, M.Z.; Cao, C.Y.; Li, S.H.; Tang, Y.X.; Wang, L.N.; Qi, N.; Huang, J.Y.; Zhang, K.Q.; Al-Deyab, S.S.; Lai, Y.K. In situ plasmonic $\mathrm{Ag}$ nanoparticle anchored $\mathrm{TiO}_{2}$ nanotube arrays as visible-light-driven photocatalysts for enhanced water splitting. Nanoscale 2016, 8, 5226-5234. [CrossRef] [PubMed]

20. Shengyan, P.; Rongxin, Z.; Hui, M.; Daili, D.; Xiangjun, P.; Fei, Q.; Wei, C. Facile in-situ design strategy to disperse $\mathrm{TiO}_{2}$ nanoparticles on graphene for the enhanced photocatalytic degradation of rhodamine 6G. Appl. Catal. B 2017, 218, 208-219. [CrossRef]

21. Singh, A.; Sinha, A.S.K. Active CdS/rGO photocatalyst by a high temperature gas-solid reaction for hydrogen production by splitting of water. Appl. Surf. Sci. 2018, 430, 184-197. [CrossRef]

22. Yang, N.; Zhai, J.; Wang, D.; Chen, Y.; Jiang, L. Two-Dimensional Graphene Bridges Enhanced Photoinduced Charge Transport in Dye-Sensitized Solar Cells. ACS Nano 2010, 4, 887-894. [CrossRef]

23. Pan, X.; Yi, Z. Graphene Oxide Regulated Tin Oxide Nanostructures: Engineering Composition, Morphology, Band Structure, and Photocatalytic Properties. ACS Appl. Mater. Interfaces 2015, 7, 27167-27175. [CrossRef]

24. Tan, L.L.; Ong, W.J.; Chai, S.P.; Mohamed, A.R. Reduced graphene oxide- $\mathrm{TiO}_{2}$ nanocomposite as a promising visible-light-active photocatalyst for the conversion of carbon dioxide. Nanoscale Res. Lett. 2013, 8, 465. [CrossRef] [PubMed]

25. Wang, P.; Wang, J.; Wang, X.; Yu, H.; Yu, J.; Lei, M.; Wang, Y. One-step synthesis of easy-recycling TiO $2-r G O$ nanocomposite photocatalysts with enhanced photocatalytic activity. Appl. Catal. B 2013, 132-133, 452-459. [CrossRef]

26. Zeng, X.; Wang, Z.; Wang, G.; Gengenbach, T.R.; McCarthy, D.T.; Deletic, A.; Yu, J.; Zhang, X. Highly dispersed $\mathrm{TiO}_{2}$ nanocrystals and $\mathrm{WO}_{3}$ nanorods on reduced graphene oxide: Z-scheme photocatalysis system for accelerated photocatalytic water disinfection. Appl. Catal. B 2017, 218, 163-173. [CrossRef]

27. Koss, A.R.; Gouw, J.D.; Warneke, C.; Gilman, J.B.; Lerner, B.M.; Graus, M.; Yuan, B.; Edwards, P.; Brown, S.S.; Wild, R.; et al. Photochemical aging of volatile organic compounds associated with oil and natural gas extraction in the Uintah Basin, UT, during a wintertime ozone formation event. Atmos. Chem. Phys. 2015, 15, 5727-5741. [CrossRef]

28. Torpy, F.; Clements, N.; Pollinger, M.; Dengel, A.; Mulvihill, I.; He, C.; Irga, P. Testing the single-pass VOC removal efficiency of an active green wall using methyl ethyl ketone (MEK). Air Qual. Atmos. Health 2018, 11, 163-170. [CrossRef] [PubMed] 
29. Mungse, H.P.; Sharma, O.P.; Sugimura, H.; Khatri, O.P. Hydrothermal deoxygenation of graphene oxide in sub- and supercritical water. RSC Adv. 2014, 4, 22589-22595. [CrossRef]

30. Zhou, Y.; Bao, Q.; Tang LA, L.; Zhong, Y.; Loh, K.P. Hydrothermal Dehydration for the "Green" Reduction of Exfoliated Graphene Oxide to Graphene and Demonstration of Tunable Optical Limiting Properties. Chem. Mater. 2009, 21, 2950-2956. [CrossRef]

31. Li, D.; Duan, X.; Qin, Q.; Fan, H.; Zheng, W. Ionic liquid-assisted synthesis of mesoporous $\alpha-\mathrm{Ga}_{2} \mathrm{O}_{3}$ hierarchical structures with enhanced photocatalytic activity. J. Mater. Chem. A 2013, 1, 12417-12421. [CrossRef]

32. Zhao, W.; Yang, Y.; Hao, R.; Liu, F.; Wang, Y.; Tan, M.; Tang, J.; Ren, D.; Zhao, D. Synthesis of mesoporous $\beta$ - $\mathrm{Ga}_{2} \mathrm{O}_{3}$ nanorods using PEG as template: Preparation, characterization and photocatalytic properties. J. Hazard. Mater. 2011, 192, 1548-1554. [CrossRef] [PubMed]

33. Shen, J.F.; Yan, B.; Shi, M.; Ma, H.; Li, N.; Ye, M. One step hydrothermal synthesis of $\mathrm{TiO}_{2}$-reduced graphene oxide sheets. J. Mater. Chem. 2011, 21, 3415-3421. [CrossRef]

34. Hu, K.; Xie, X.; Szkopek, T.; Cerruti, M. Understanding Hydrothermally Reduced Graphene Oxide Hydrogels: From Reaction Products to Hydrogel Properties. Chem. Mater. 2016, 28, 1756-1768. [CrossRef]

35. Xu, Y.; Sheng, K.; Li, C.; Shi, G. Self-Assembled Graphene Hydrogel via a One-Step Hydrothermal Process. ACS Nano 2010, 4, 4324-4330. [CrossRef]

36. Bai, X.; Wang, L.; Zong, R.; Lv, Y.; Sun, Y.; Zhu, Y. Performance Enhancement of ZnO Photocatalyst via Synergic Effect of Surface Oxygen Defect and Graphene Hybridization. Langmuir 2013, 29, 3097-3105. [CrossRef] [PubMed]

37. Li, Q.; Guo, B.; Yu, J.; Ran, J.; Zhang, B.; Yan, H.; Gong, J.R. Highly Efficient Visible-Light-Driven Photocatalytic Hydrogen Production of CdS-Cluster-Decorated Graphene Nanosheets. J. Am. Chem. Soc. 2011, 133, 10878-10884. [CrossRef]

38. Soltani, T.; Lee, B.K. A benign ultrasonic route to reduced graphene oxide from pristine graphite. J. Colloid Interface Sci. 2017, 486, 337-343. [CrossRef]

39. Gollu, S.R.; Sharma, R.; Srinivas, G.; Kundu, S.; Gupta, D. Incorporation of silver and gold nanostructures for performance improvement in P3HT: PCBM inverted solar cell with $\mathrm{rGO} / \mathrm{ZnO}$ nanocomposite as an electron transport layer. Org. Electron. 2016, 29, 79-87. [CrossRef]

40. Xu, T.; Zhang, L.; Cheng, H.; Zhu, Y. Significantly enhanced photocatalytic performance of ZnO via graphene hybridization and the mechanism study. Appl. Catal. B 2011, 101, 382-387. [CrossRef]

41. Williams, G.; Kamat, P.V. Graphene-Semiconductor Nanocomposites: Excited-State Interactions between ZnO Nanoparticles and Graphene Oxide. Langmuir 2009, 25, 13869-13873. [CrossRef]

42. Wu, F.; Wang, X.; Li, M.; Xu, H. A high capacity NiFe2O4/RGO nanocomposites as superior anode materials for sodium-ion batteries. Ceram. Int. 2016, 42, 16666-16670. [CrossRef]

43. Khatamian, M.; Khodakarampoor, N.; Oskoui, M.S.; Kazemian, N. Synthesis and characterization of RGO/zeolite composites for the removal of arsenic from contaminated water. RSC Adv. 2015, 5, 35352-35360. [CrossRef]

44. Li, J.; Xing, X.; Li, J.; Shi, M.; Lin, A.; Xu, C.; Zheng, J.; Li, R. Preparation of thiol-functionalized activated carbon from sewage sludge with coal blending for heavy metal removal from contaminated water. Environ. Pollut. 2018, 234, 677-683. [CrossRef] [PubMed]

45. Hummers, W.S., Jr.; Offeman, R.E. Preparation of Graphitic Oxide. J. Am. Chem. Soc. 1958, 80, 1339. [CrossRef]

(C) 2019 by the authors. Licensee MDPI, Basel, Switzerland. This article is an open access article distributed under the terms and conditions of the Creative Commons Attribution (CC BY) license (http://creativecommons.org/licenses/by/4.0/). 